DOI: $10.21802 /$ artm.2020.1.13.60.

УДК 616.316-008.8-078-06:616.314-002:618.33-007.1

\title{
ДИНАМІКА БІОХІМІЧНИХ ПОКАЗНИКІВ РОТОВОЇ РІДИНИ ЯК МАРКЕР РИЗИКУ РОЗВИТКУ КАРІОЗНИХ УРАЖЕНЬ У ОСІБ РІЗНОГО ВІКУ, ЯКІ НАРОДИЛИСЬ МАКРОСОМАМИ
}

\author{
О.В. Гармаш
}

Харківський національний медичний університет, кафедра терапевтичної стоматології, м. Харків, Украӥна,

ORCID ID: 0000-0001-7935-9371,e-mail:o.v.garmash@gmail.com

Резюме. Висока інтенсивність карієсу у осіб, які були народжені великими до гестаційного віку, спонукає науковців до пошуку біохімічних критеріїв ранньої та диференційної діагностики.

Мета дослідження: вивчення взаємозалежності між динамікою рівнів лептину, адипонектину, кортизолу, ТБК-АП та ІЛ-6, а також активністю $\alpha$-амілази каталази та СОД в нестимульованій ротовій рідині осіб популяції Харківської області та прилеглих областей, які народились із макросомією (враховуючи антропометричні показники при народженні) / нормосомією та інтенсивністю карієсу тимчасових та постійних зубів.

Матеріали та методи дослідження. Обстежено 210 осіб віком від 4 до 55 років. Учасники основної групи (народжені макросомами) були розділені на підгрупи, враховуючи антропометричні показники при народженні та гормональні особливості внутрішньоутробного періоду.

Результати. В учасників дослідження, віднесених до підгруп 3 (велика довжина та велика маса тіла при народженні) і 4 (середня довжина та надмірна маса тіла при народженні), виявлено значне зростання концентрації лептину та кортизолу з одночасним зниженням рівнів адипонектину в ротовій рідині, що свідчить про дисбаланс адіпокінів і формування метаболічного запалення. Зростання рівня ТБК-АП і зниження активності супероксиддисмутази, каталази і $\alpha$-амілази та підвищення рівня інтерлейкіну-6 в ротовій рідині негативно впливають на стан кісткової тканини і узгоджуються з даними про схильність до високої інтенсивності карієсу у цих осіб. У підгрупах 1 (гармонійно розвинені при народженні) та 2 (збільшена довжина тіла та відносно знижена маса тіла при народженні) в умовах нашого дослідження більш сприятливий прогноз стану кісткової тканини i, зокрема, твердих тканин зубів.

Висновки. Прогноз щодо стану твердих тканин зубів у осіб підгрупи 1 та $2 €$ більш сприятливим, ніж у осіб підгруп 3 та 4.

Ключові слова: макросомія плоду, віддалені наслідки, карієс, ротова рідина, біохімічні маркери.

Вступ. Незважаючи на великі зусилля, які витрачає світова медична спільнота на профілактику карієсу, порушень прикусу та інших стоматологічних порушень, стан проблеми є критичним.

Макросомія плоду (маса тіла на момент народження, яка є більшою, або дорівнює 4 кг) є незалежним маркером у формуванні метаболічних порушень у подальшому житті. Раніше доведено, що особам, народженим із макросомією, притаманна висока інтенсивність карієсу як тимчасових, так і постійних зубів $[1,2,3]$. Уже на момент народження особи, які народились макросомами, мали предиктори метаболічних порушень, оскільки у них було зафіксовано високі рівні лептину та тенденцію до зниження рівнів адипонектину у сироватці крові [4].

Обгрунтування дослідження. Гормони жирової тканини лептин і адипонектин $є$ біологічними маркерами багатьох патологічних станів та захворювань, у тому числі процесів запалення. Визначення рівнів цих цитокінів у ротовій рідині (РP) із метою діагностики метаболічних порушень стає все більш популярною i, на думку численних дослідників, не менш інформативною процедурою, ніж дослідження їх рівнів у препаратах крові. Відомо, що лептин гормон, який продукується адипоцитами відповідно до маси жирової тканини, але у невеликій кількості $€$ також у плаценті, слизовій шлунку та слинних залозах. Він відноситься до гуморальних регуляторів харчової поведінки та діє безпосередньо через гіпоталамус - надаючи анорексигенного ефекту. Проведені дослідження виявили, що підвищений рівень прозапальних цитокінів, таких як лептин чи інтерлейкін 6 (ІЛ-6), може використовуватись як маркер запальних процесів навіть тоді, коли інші біологічні маркери ще «мовчать», тобто на доклінічній стадії патологічного процесу [5].

Залежність мінеральної щільності кісткової тканини від співвідношення рівнів лептину та адипонектину в біологічних рідинах також $\epsilon$ темою досить розробленою. Низка учених вказує на те, що підвищення рівня лептину інгібує утворення кісткової тканини [6]. Більш пізні дослідження виявили, що ущільнення кісткової тканини щелеп прямо пропорційне підвищенню рівня слинного лептину. На думку дослідників, висока мінеральна щільність кісткової тканини уповільнює швидкість переміщення зубів при ортодонтичному лікуванні [7].

Добре відомо, що баланс кортизолу та соматотропного гормону (СТГ) під час внутрішньоутробного розвитку у значній мірі визначають особливості 
перебігу метаболічних процесів після народження, що своєю чергою може стати підгрунтям для формування схильності до певних захворювань (в тому числі - стоматологічних порушень).

Вивчення антиоксидантно-прооксидантної рівноваги широко використовується при дослідженні стоматологічних порушень [8]. У роботі Криштоп В.В. та співавторів доведено, що рівень продуктів, які реагують із тіобарбітуровою кислотою (ТБК-АП) РР, хоч і залежить від загальносоматичного стану, проте значною мірою є віддзеркаленням стоматологічного статусу обстеженої особи [9]. Також відомо, що при зниженні рівнів амілази РР відбувається зниження іiі протективних властивостей [10].

Беручи до уваги зазначене, нами було проведено визначення вмісту лептину, адипонектину, кортизолу та ІЛ-6, досліджена активність ключових ферментів антиоксидантного захисту - супероксиддисмутази (СОД) та каталази, активність $\alpha$-амілази, а також рівнів продуктів перикисного окиснення ліпідів (ПОЛ) - ТБК-АП у РР учасників дослідження.

Мета дослідження: вивчення взаємозалежності між динамікою рівнів лептину, адипонектину, кортизолу, ІЛ-6, ТБК-АП, а також активністю СОД, каталази та $\alpha$-амілази в нестимульованій РР осіб популяції Харківської області та прилеглих областей, які народились із макросомією (враховуючи антропометричні показники при народженні)/нормосомією та інтенсивністю карієсу тимчасових i постійних зубів.

Матеріали і методи дослідження. Із групи раніше обстежених осіб $[1,2,3]$ для проведення дослідження випадковим чином були відібрані 210 осіб віком від 4 до 55 років. Серед них були 163 особи (основна група), чиї параметри при народженні оцінювались як макросомія плоду, та 47 осіб відповідного віку, чиї параметри при народженні відповідали нормі (група порівняння).

Існують відомості, що рівень досліджуваних цитокінів коливається не тільки залежно від віку учасника дослідження, а й від статі, зокрема, така залежність підсилюється у дітей із метаболічними порушеннями. Тому групи є рівно представленими за кількістю учасників чоловічої і жіночої статі. У жінок було враховано фазу менструального циклу.

Для більшої надійності порівняння отриманих результатів обстежені були розділені на вікові періоди. Перший віковий період об'єднував дітей віком від 4 до 6 років, другий - дітей від 7 до 11 років, третій віковий період - підлітків пубертатного розвитку (12 - 17 років). Учасники дослідження віком від 18 до 34 років були віднесені до четвертого періоду, від 35 до 44 років - до п'ятого, та від 45 до 55 років - до шостого вікового періоду.

У ряді попередніх досліджень було доведено, що стоматологічний статус осіб із макросомією на момент народження суттєво залежить від індексу маси тіла при народженні. Спираючись на класифікацію новонароджених макросомів, запропонованою Грищенко В.І. та співавторами, яка детально викладена у роботах $[1,2,3]$, усі учасники дослідження були розділені на підгрупи.
До підгрупи 1 були віднесені довгі, гармонійно розвинені при народженні особи, їх індекс маси тіла на момент народження був зіставним із групою порівняння (ГП). Відповідно до гормональних особливостей розвитку ці особи внутрішньоутробно мали підвищений рівень СТГ та відносну нестачу кортизолу.

До підгрупи 2 віднесли осіб із збільшеною довжиною тіла та відносно зниженою масою тіла при народженні, тобто їх пренатальний розвиток відбувався на фоні підвищеного рівню СТГ та більш вираженій ніж у осіб підгрупи 1 нестачі кортизолу,

До підгрупи 3 були віднесені особи, які мали велику довжину та велику масу тіла при народженні. Такі особи мали підвищений рівень СТГ і кортизолу. За даними Грищенко та співавторів, у таких новонароджених спостерігалась внутрішньоутробна акселерація на фоні ожиріння.

До підгрупи 4 були віднесені учасники дослідження, які при народженні мали середню довжину тіла, але виражену надмірну масу тіла, їх внутрішньоутробний розвиток проходив при підвищеному рівні кортизолу та при відносній нестачі СТГ. Осереднені значення масо-ростових параметрів усіх учасників дослідження 3 відповідними коефіцієнтами гармонійності при народженні опубліковані в роботах $[1,2,3]$. Дані про антропометричні показники при народженні в учасників дослідження були отримані 3 історій розвитку дітей, медичних карт стаціонарного хворого або іншої документації, яка збереглася в архівах медичних закладів або безпосередньо в учасників дослідження.

До дослідження не залучались особи, в яких було виявлені системні захворювання або інші захворювання на стадії декомпенсації, гострий стрес в анамнезі, вагітність або годування груддю, паління, проведення радіотерапії, вживання будь-яких медикаментозних препаратів, у тому числі контрацептивів, ортодонтичне лікування. На момент включення у дослідження усі учасники, за даними лікарів інших спеціальностей, не мали виявленої супутньої патології та їх індекс маси тіла знаходився у межах між 18,5$30 \mathrm{\kappa г} / \mathrm{M}^{2}$, тобто вони не мали ні дефіциту маси тіла ні ожиріння. Всі учасники дослідження, або їхні батьки, якщо мова йшла про участь неповнолітньої дитини, письмово погодились прийняти участь у дослідженні.

Біохімічні дослідження ротової рідини. Ротова рідина збиралась натще в ранкові години $\left(8^{00}-\right.$ $\left.9^{00}\right)$. Після споліскування ротової порожнини учасники досліджування нахиляли голову так, щоб РР вільно витікала в мірну пробірку. Розділену на декілька порцій промарковану нестимульовану РP зберігали при температурі $-20^{\circ}$.

Вміст лептину та адипонектину в ротовій рідині визначали імуноферментним методом (IФМ) наборами Leptin ELISA та Adiponectin ELISA («Mediagnost», Німеччина). Вміст ІЛ-6 визначали ІФМ за допомогою стандартного набору реактивів (Вектор Бест, Р.Ф.) на мікропланшетному аналізаторі «LisaScan» фирмы «Erba Lachema» (Чеська республіка). 
Рівень кортизолу визначався ІФМ (набір НВЛ «Гранум», Україна) на мікропланшетному імуноферментному аналізаторі «Stat Fax 4700» фірми «Awareness technology inc.» (США). Активність СОД визначали за методом Woolliams T.A. et al., (1983) [11]. Активність каталази визначалась за реакцією перекису водню $з$ молібдатом амонію за методикою Королюка М.А. та співавторів [12]. Визначення активності $\alpha$-амілази проводили із використанням набо-

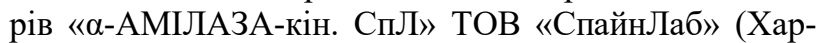
ків, Україна) згідно рекомендацій виробника. Вміст ТБК-активних продуктів визначали в реакції з 2-тіобарбітуровою кислотою [13].

Через різну кількість отриманої РР, а також через те, що різні набори розраховані на різну кількість визначень, загальна кількість осіб $n$, обстежених тим чи іншим методом, змінювалась. Конкретні значення $n$ вказані в таблицях поряд із визначеними біохімічними показниками.

Статистична обробка результатів здійснювалась за допомогою програми Microsoft Excel 2016 (ліцензійний номер 67844311, 2016) та пакету STATISTICA 13 (тріал-версія, URL: http://statsoft.ru/ products/trial/, дата звернення 18.06.2019). Одержані в результаті дослідження дані представлені у вигляді медіани (Ме) та інтерквартильного розмаху (Q3;Q1). Перевірка гіпотез про відмінність середніх у малих групах проводилась методами непараметричної статистики (за критерієм Манна - Уітні).

Результати дослідження та їх обговорення. Рівні вмісту лептину та адипонектину, які продукуються жировою тканиною в РР учасників дослідження, демонструє таблиця 1. Нами було виявлено високі значення вмісту лептину в РP пацієнтів усіх вікових періодів у підгрупах 3 та 4. Найбільш виражене підвищення спостерігалось у осіб підгрупи 4.

Ми це пов'язуємо із тим, що внутрішньоутробний розвиток цих осіб проходив за умов гіперкортизолемії. Відомо, що кортизол є потужним стимулятором збільшення маси жирової тканини, що прямо корелює із збільшенням продукції лептину адипоцитами. У осіб підгрупи 3 також мала місце гіперкортизолемія, проте, зважаючи на їх масо-ростові параметри на момент народження, у них був також підвищений рівень СТГ, що надавало додаткового впливу на диференціювання преадипоцитів та робило внесок у збільшення маси жирової тканини. Це також корелює із збільшенням продукції лептину.

Слід зазначити, що в осіб підгруп 3 та 4 зростання концентрації лептину збільшувалось із віком. Такі зміни, імовірно, були обумовлені формуванням стану лептинорезистентності, яка поглиблювалась із віком. За таких умов відбуваються порушення фізіологічних функцій лептину, наслідком чого $є$ формування та прогресування інсулінорезистентності, в тому числі - за рахунок збільшення продукції прозапальних цитокінів.

Водночас у осіб, що були віднесені до підгрупи 1, хоча медіанні значення рівнів лептину за усі вікові періоди разом були достовірно вищими за такі у групі порівняння, у кожному віковому періоді окремо (за вийнятком ВП IV) не спостерігалось достовірно збільшених його концентрацій, порівняно 3 контролем (табл.1). У підгрупі 2 цей показник навіть був зниженим. Це, очевидно, було обумовлено високим вмістом СТГ за відносного дефіциту кортизолу, внаслідок чого формування жирової тканини дещо пригнічувалось.

Наступним етапом наших досліджень було визначення вмісту в РР одного із адипокінів, що продукуються жировою тканиною - адипонектину (табл.1), який має низку позитивних метаболічних ефектів - пригнічує диференціювання преадипоцитів, знижує інтенсивність глюконеогенезу, збільшує чутливість клітин до дії інсуліну та, в цілому, знижує кардіометаболічний ризик.

Стійка тенденція до зниження рівня адипонектину в РР пацієнтів підгруп 3 та 4 порівняно 3 контрольними показниками, за одночасного зростання концентрації лептину, свідчила про формування дисбалансу адипокінів, характерного для метаболічного запалення. При цьому більш виражене зниження рівня адипонектину спостерігалось у осіб підгрупи 4 та прогресувало з віком. Очевидно, це було обумовлено гіперкортизолемією, яка первинно була характерною саме для цієї групи, оскільки відомо, що кортизол пригнічує продукцію адипонектину адипоцитами. У підгрупі 1 та 2 рівень адипонектину суттєво не відрізнявся від групи порівняння, проте у групі 2 його концентрація була найбільшою. Ми це пов'язуємо із відносним надлишком СТГ, який є стимулятором його синтезу. Виявлений у 3 та 4 групах дисбаланс лептину та адипонектину можна розглядати як маркер наявного метаболічного запалення. Вiдомо, що досить тривалий час інсулінорезистеність може перебігати безсимптомно, а тому в сучасній клінічній практиці часто застосовують інтегративний показник - співвідношення лептин/адипонектин (L/A), який на сьогоднішній день розглядається як прогностичний критерій кардіометаболічного ризику та глибини порушень метаболічних процесів [14].

Зокрема, зростання цього індексу прямо пропорційне збільшенню ризику кардіоваскулярних ускладнень та інтенсивності метаболічного запалення. Останнє, як відомо, суттєво впливає на обмінні процеси у кістковій тканині, зокрема - активує пї деградацію та порушує процеси остеогенезу. Нами було виявлено, що у осіб підгруп 3 та 4 спостерігалось значне зростання індексу L/A. Найбільш вираженим воно було в осіб підгрупи 4, що узгоджувалось iз даними їхнього стоматологічного обстеження - у них було зафіксовано високу інтенсивність карієсу [1, 2, 3]. У підгрупах 1 та 2 індекс L/A в більшості випадків був співставним із ГП, що за умов нашого дослідження може розглядатись як більш сприятливий прогноз щодо стану кісткової тканини, зокрема твердих тканин зубів.

Наше припущення щодо формування метаболічного запалення в осіб підгруп 3 та 4 підтверджувалось також динамікою вмісту кортизолу (табл. 2), який у осіб цих підгруп у більшості вікових періодів був достовірно вищим від контрольних значень та збільшувався із віком.

Особливо виражене зростання цього показника спостерігалось у осіб підгрупи 4, які первинно мали гіперкортизолемію. Кортизол здатен впливати 
на цілу низку метаболічних ланок, в тому числі регулювати метаболічну та ендокринну активність жирової тканини, що узгоджувалось із отриманими нами даними щодо збільшення рівня лептину і зниження адипонектину. У ряді досліджень була виявлена зворотна кореляція між рівнем адипонектину та кортизолу, що є характерним для формування загального прозапального стану [15]. Це також узгоджується 3 нашим припущенням щодо метаболічного запалення в осіб підгруп 3 та 4. Крім того відомо, що тривала гіперкортизолемія негативно впливає на стан кісткової тканини [16], сприяючи іiї деструкції, що підтверджується наявністю схильності до карієсу у осіб зазначених груп.

В учасників дослідження підгрупи 2 не спостерігалось вірогідних змін рівня кортизолу в РР відносно контрольних значень (табл.2). Це пов'язано із первинним зсувом співвідношення СТГ/кортизол у підгрупі 2 та асоційовано із стимуляцією за дії СТГ синтезу альдостерону, який має із кортизолом спільні біосинтетичні шляхи [17]. Хоча медіанні значення рівня кортизолу в учасників підгрупи 1 за всі вікові періоди разом (табл.2) були вірогідно вищими за контрольні, у окремих вікових періодах вони вірогідно не відрізнялись від контрольних. Це може пояснюватись тим, що внутрішньоутробний розвиток таких осіб протікав за умов більш гармонійного співвідношення СТГ та кортизолу, ніж у осіб підгрупи 2.

Відомо, що розвиток метаболічного запалення супроводжується гіперпродукцією прозапальних цитокінів, серед яких інтерлейкіни, фактор некрозу пухлини-альфа тощо. Було виявлено зміни продукції ІЛ-6 (табл. 2), рівень якого зростав у осіб підгруп 3 та 4. Тенденція до цих змін поглиблювалась із віком внаслідок прогресування у таких осіб метаболічного запалення.

У науковій літературі ІЛ-6 розглядається як важливий фактор поглиблення та обтяження гіперкортизолемії (яка за умов наших спостережень збільшувалась із віком) за рахунок стимуляції гіпоталамогіпофізарно-надниркової вісі. Крім того, доведена роль ІЛ-6 у формуванні ризику карієсу тимчасових зубів [18].

У результаті досліджень, проведених раніше $[1,2,3]$, виявлено, що в осіб макросомів-принародженні, які народились із ознаками надмірної маси тіла (підгрупи 3 та 4), інтенсивність каріозного процесу $\epsilon$ вищою, ніж у осіб макросомів-принародженні відповідного віку, чиї параметри при народженні вказували на відсутність надмірної маси тіла (підгрупи 1 та 2). В осіб підгрупи 1 нами не було виявлено суттєвих змін рівня ІЛ-6, проте у пацієнтів підгрупи 2 мала місце тенденція до зростання цього показника, очевидно, обумовлена надлишком СТГ, який стимулював синтез білків, включаючи сімейство інтерлейкінів. Найбільші, проте не вірогідно збільшені відносно групи порівняння, показники ІЛ-6 у осіб 2 групи спостерігались у віці $18-45$ років.

Суттєво зменшена активність $\alpha$-амілази (табл. 2) в РР дітей основної групи першого вікового періоду пояснюється високою інтенсивністю карієсу тимчасових зубів у макросомів-при-народженні [1]. Вірогідне зниження активності $\alpha$-амілази ротової рідини в осіб підгрупи 4 та, в більшості випадків, у осіб підгрупи 3 в усіх вікових періодах (табл. 2) пов'язане із продуктами життєдіяльності патогенних мікроорганізмів, що знижують $\mathrm{pH}$ ротової рідини. Внаслідок цього активність ферменту теж знижується, що є характерним при високій інтенсивності каріозного процесу, виявленій у таких осіб. В осіб підгруп 1 і 2 у віці 7 років і старших зазначених змін не спостерігалось.

Наступним етапом наших досліджень було вивчення антиоксидантно-прооксидантної рівноваги (табл. 3).

Відомо, що в ранньому дитячому віці активність ПОЛ $є$ досить інтенсивною внаслідок недосконалості ферментних систем антиоксидантного захисту. Високі значення ТБК-АП, зафіксовані нами у дітей, народжених макросомами, віком $3-6$ років (навіть у тих, чий внутрішньоутробний розвиток оцінювався нами як гармонійний - підгрупа 1) [1], можуть бути поясненням високої інтенсивності карієсу тимчасових зубів [8], для якого характерним $є$ зсув співвідношення антиоксидантних та прооксидантних факторів.

У нормі, з віком баланс антиоксидантних факторів вирівнюється, і ПОЛ пригнічується. Переважання прооксидантних факторів робить вагомий внесок у патогенез метаболічних порушень і поглиблює загальний прозапальний стан. Нами було виявлено підвищення рівня ТБК-АП в усіх вікових періодах, більш суттєве у групах $2-4$. Поєднуючи ці відомості 3 вірогідним зниженням рівня каталази та СОД, яке у більшості випадків має місце в осіб підгруп 3 та 4, можна припускати місцеве послаблення антиоксидантного захисту ротової порожнини та, як наслідок, виникнення умов до підвищення інтенсивності карієсу.

Як демонструє таблиця 3, в осіб підгруп 3 та 4 мало місце підвищення ТБК-АП. У підгрупах 2 та 3 інтенсифікація ПОЛ і більш виражене збільшення вмісту ТБК-АП спостерігалось у віці до 18 років. Тут мали місце високі рівні СТГ і кортизолу, які є гуморальними активаторами ПОЛ. Також спостерігалось зниження ферментних антиоксидантів, особливо виражене у підгрупах 3 та 4, мала місце тенденція до зменшення показників із віком. Цей ефект може бути пов'язаним із гіперпродукцією прозапального ІЛ-6, відомим результатом якої є активація ПОЛ. У більшості осіб підгрупи 2, особливо в молодому віці, таких виразних змін активності СОД і каталази не спостерігалось (табл. 3), що, ймовірно, було обумовлено інтенсифікацією біосинтезу білка під впливом високих концентрацій СТГ. У старшому віковому періоді, де спостерігається виснаженість компенсаторних механізмів антиоксидантного захисту [19], найменші медіанні значення ТБК-АП серед осіб основної групи зафіксовані у осіб підгрупи 1. 
Таблиця 1

Медіанні значення Мe(Q3;Q1) показників лептину (нг/мл) та адипонектину (нг/мл) та їх співвідношення L/A (ум.од.) у ротовій рідині учасників дослідження та кількість обстежених осіб (n) в кожній групі чи підгрупі

\begin{tabular}{|c|c|c|c|c|c|c|}
\hline $\begin{array}{c}\text { Група, } \\
\text { підгрупа }\end{array}$ & Порівняння & Основна & Підгрупа 1 & Підгрупа 2 & Підгрупа 3 & Підгрупа 4 \\
\hline \multicolumn{7}{|c|}{ ВП I (4-6 років) } \\
\hline Лептин & $\begin{array}{c}0,465 \\
(0,645 ; 0,283) \\
n=5\end{array}$ & $\begin{array}{c}2,460^{*} \\
(6,998 ; 1,077) \\
p=0,02090, n=20\end{array}$ & $\begin{array}{c}1,664 \\
(2,113 ; 1,231) \\
p=0,02828, n=5\end{array}$ & $\begin{array}{c}0,386 \\
(0,413 ; 0,255) \\
n=5\end{array}$ & $\begin{array}{c}6,433 * \\
(9,122 ; 2,557) \\
p=0,00902, n=5\end{array}$ & $\begin{array}{c}8,691^{*} \\
(10,207 ; 3,378) \\
p=0,00902, n=5\end{array}$ \\
\hline $\begin{array}{l}\text { Адипонект } \\
\text { ин }\end{array}$ & $\begin{array}{c}0,679 \\
(0,756 ; 0,601) \\
n=5\end{array}$ & $\begin{array}{c}1,324 \\
(1,469 ; 0,778) \\
n=20\end{array}$ & $\begin{array}{c}1,560 \\
(2,005 ; 0,855) \\
\mathrm{n}=5\end{array}$ & $\begin{array}{c}1,392^{*} \\
(2,474 ; 1,361) \\
p=0,01629, n=5\end{array}$ & $\begin{array}{c}0,917 \\
(1,321 ; 0,472) \\
\mathrm{n}=5\end{array}$ & $\begin{array}{c}0,793 \\
(1,424 ; 0,731) \\
n=5\end{array}$ \\
\hline $\mathrm{L} / \mathrm{A}$ & 0,68 & 1,86 & 1,07 & 0,28 & 7,02 & 10,96 \\
\hline \multicolumn{7}{|c|}{ ВП ІІ (7-11 років) } \\
\hline Лептин & $\begin{array}{c}0,532 \\
(0,958 ; 0,272) \\
\mathrm{n}=5\end{array}$ & $\begin{array}{c}4,576^{*} \\
(7,627 ; 0,895) \\
p=0,01446, n=20\end{array}$ & $\begin{array}{c}1,766 \\
(2,213 ; 0,422) \\
\mathrm{n}=5\end{array}$ & $\begin{array}{c}0,652 \\
(0,976 ; 0,451) \\
\mathrm{n}=5\end{array}$ & $\begin{array}{c}6,106^{*} \\
(8,974 ; 4,322) \\
p=0,00902, n=5\end{array}$ & $\begin{array}{c}8,814^{*} \\
(10,849 ; 5,125) \\
p=0,02902, n=5\end{array}$ \\
\hline $\begin{array}{l}\text { Адипонек- } \\
\text { тин }\end{array}$ & $\begin{array}{c}0,640 \\
(0,849 ; 0,565) \\
n=5\end{array}$ & $\begin{array}{c}0,739 \\
(1,514 ; 0,588) \\
\mathrm{n}=20\end{array}$ & $\begin{array}{c}1,371 \\
(1,691 ; 0,785) \\
\mathrm{n}=5\end{array}$ & $\begin{array}{c}1,417 \\
(1,492 ; 0,692) \\
\mathrm{n}=5\end{array}$ & $\begin{array}{c}0,622 \\
(1,709 ; 0,612) \\
\mathrm{n}=5\end{array}$ & $\begin{array}{c}0,591 \\
(0,671 ; 0,552) \\
\mathrm{n}=5\end{array}$ \\
\hline $\mathrm{L} / \mathrm{A}$ & 0,83 & 6,19 & 1,29 & 0,46 & 9,82 & 14,91 \\
\hline \multicolumn{7}{|c|}{ ВП ІІІ (12-17 років) } \\
\hline Лептин & $\begin{array}{c}0,894 \\
(0,900 ; 0,253) \\
n=5\end{array}$ & $\begin{array}{c}1,855^{*} \\
(4,949 ; 0,867) \\
\mathrm{p}=0,04154 \\
\mathrm{n}=20\end{array}$ & $\begin{array}{c}1,634 \\
(2,888 ; 0,890) \\
n=5\end{array}$ & $\begin{array}{c}0,603 \\
(0,797 ; 0,282) \\
n=5\end{array}$ & $\begin{array}{c}4,453^{*} \\
(4,761 ; 2,050) \\
\mathrm{p}=0,00902 \\
\mathrm{n}=5\end{array}$ & $\begin{array}{c}5,513^{*} \\
(5,950 ; 4,125) \\
\mathrm{p}=0,00902 \\
\mathrm{n}=5\end{array}$ \\
\hline $\begin{array}{l}\text { Адипонект } \\
\text { ин }\end{array}$ & $\begin{array}{c}0,972 \\
(0,975 ; 0,647) \\
n=5\end{array}$ & $\begin{array}{c}0,763 \\
(1,261 ; 0,623) \\
n=20\end{array}$ & $\begin{array}{c}1,237 \\
(1,131 ; 0,761) \\
n=5\end{array}$ & $\begin{array}{c}1,648 \\
(2,073 ; 0,964) \\
n=5\end{array}$ & $\begin{array}{c}0,697 \\
(0,721 ; 0,620) \\
n=5\end{array}$ & \begin{tabular}{l}
\multicolumn{1}{c}{$0,479^{*}$} \\
$(0,624 ; 0,453)$ \\
$p=0,04720, n=5$
\end{tabular} \\
\hline $\mathrm{L} / \mathrm{A}$ & 0,92 & 2,43 & 1,32 & 0,37 & 6,39 & 11,51 \\
\hline \multicolumn{7}{|c|}{ ВП IV (18-34 роки) } \\
\hline Лептин & $\begin{array}{c}0,856 \\
(0,933 ; 0,329) \\
n=7\end{array}$ & $\begin{array}{c}1,771^{*} \\
(5,451 ; 0,961) \\
p=0,00353, n=25\end{array}$ & $\begin{array}{c}1,239^{*} \\
(1,734 ; 1,147) \\
p=0,01013, n=6\end{array}$ & $\begin{array}{c}0,856 \\
(0,961 ; 0,361) \\
n=5\end{array}$ & $\begin{array}{c}6,318^{*} \\
(8,959 ; 1,357) \\
p=0,01809, n=7\end{array}$ & $\begin{array}{c}6,556^{*} \\
(6,953 ; 4,220) \\
p=0,00175, n=7\end{array}$ \\
\hline $\begin{array}{l}\text { Адипонект } \\
\text { ин }\end{array}$ & $\begin{array}{c}0,923 \\
(1,120 ; 0,819) \\
n=7\end{array}$ & $\begin{array}{c}0,787 \\
(1,193 ; 0,610) \\
n=27\end{array}$ & $\begin{array}{c}0,926 \\
(1,225 ; 0,779) \\
n=7\end{array}$ & $\begin{array}{c}1,256 \\
(2,189 ; 0,933) \\
n=5\end{array}$ & $\begin{array}{c}0,641^{*} \\
(0,727 ; 0,549) \\
p=0,02535, n=7\end{array}$ & $\begin{array}{c}0,626 \\
(1,051 ; 0,576) \\
n=8\end{array}$ \\
\hline $\mathrm{L} / \mathrm{A}$ & 0,93 & 2,25 & 1,34 & 0,68 & 9,86 & 10,47 \\
\hline \multicolumn{7}{|c|}{ ВП V (35-44 роки) } \\
\hline Лептин & $\begin{array}{c}1,045 \\
(1,700 ; 0,290) \\
n=5\end{array}$ & $\begin{array}{c}4,389 \\
(6,705 ; 0,749) \\
n=22\end{array}$ & $\begin{array}{c}0,678 \\
(1,006 ; 0,674) \\
n=5\end{array}$ & $\begin{array}{c}0,726 \\
(0,816 ; 0,329) \\
\mathrm{n}=5\end{array}$ & $\begin{array}{c}5,678^{*} \\
(6,099 ; 5,005) \\
p=0,00902, n=5\end{array}$ & $\begin{array}{c}6,903^{*} \\
(7,520 ; 5,293) \\
p=0,00448, n=7\end{array}$ \\
\hline $\begin{array}{l}\text { Адипонект } \\
\text { ин }\end{array}$ & $\begin{array}{c}1,052 \\
(1,126 ; 0,871) \\
\mathrm{n}=6\end{array}$ & $\begin{array}{c}0,822 \\
(1,097 ; 0,542) \\
n=22\end{array}$ & $\begin{array}{c}1,114 \\
(1,367 ; 0,871) \\
n=5\end{array}$ & $\begin{array}{c}1,119 \\
(1,251 ; 0,854) \\
n=5\end{array}$ & $\begin{array}{c}0,730^{*} \\
(0,803 ; 0,538) \\
p=0,02846, n=5\end{array}$ & $\begin{array}{l}0,555^{*} \\
(0,855 ; 0,488) \\
\mathrm{p}=0,03190, \mathrm{n}=7\end{array}$ \\
\hline $\mathrm{L} / \mathrm{A}$ & 0,99 & 5,34 & 0,61 & 0,65 & 7,78 & 12,44 \\
\hline \multicolumn{7}{|c|}{ ВП VI (45-55 років) } \\
\hline Лептин & $\begin{array}{c}1,250 \\
(1,376 ; 0,956) \\
n=5\end{array}$ & $\begin{array}{c}4,171 \\
(5,994 ; 1,215) \\
n=17\end{array}$ & $\begin{array}{c}0,905 \\
(1,352 ; 0,532) \\
n=4\end{array}$ & $\begin{array}{c}0,944 \\
(1,291 ; 0,599) \\
n=3\end{array}$ & $\begin{array}{c}5,121^{*} \\
(7,549 ; 4,650) \\
p=0,04720, n=5\end{array}$ & $\begin{array}{c}5,994^{*} \\
(7,950 ; 5,577) \\
p=0,00902, n=5\end{array}$ \\
\hline $\begin{array}{l}\text { Адипонек } \\
\text { тин }\end{array}$ & $\begin{array}{c}1,106 \\
(1,647 ; 0,922) \\
n=5\end{array}$ & $\begin{array}{c}0,743 \\
(1,136 ; 0,547) \\
n=17\end{array}$ & $\begin{array}{c}1,188 \\
(1,789 ; 0,848) \\
n=4\end{array}$ & $\begin{array}{c}1,136 \\
(1,284 ; 0,797) \\
n=3\end{array}$ & $\begin{array}{c}0,722^{*} \\
(0,743 ; 0,594) \\
p=0,04720, n=5\end{array}$ & $\begin{array}{c}0,719 \\
(0,893 ; 0,547) \\
n=5\end{array}$ \\
\hline $\mathrm{L} / \mathrm{A}$ & 1,13 & 5,61 & 0,76 & 0,83 & 7,09 & 8,34 \\
\hline \multicolumn{7}{|c|}{ Усі вікові періоди разом } \\
\hline Лептин & $\begin{array}{c}0,803 \\
(0,959 ; 0,288) \\
n=32\end{array}$ & $\begin{array}{c}2,460 \\
(6,345 ; 0,893) \\
p=0,00000, n=124\end{array}$ & $\begin{array}{c}1,239 * \\
(1,985 ; 0,675) \\
p=0,00142, n=30\end{array}$ & $\begin{array}{c}0,628 \\
(0,948 ; 0,329) \\
n=28\end{array}$ & $\begin{array}{c}5,353^{*} \\
(7,750 ; 3,124) \\
p=0,00000, n=32\end{array}$ & $\begin{array}{c}6,272^{*} \\
(7,916 ; 4,564) \\
p=0,00000, n=34\end{array}$ \\
\hline $\begin{array}{l}\text { Адипонек } \\
\text { тин }\end{array}$ & $\begin{array}{c}0,922 \\
(1,124 ; 0,647) \\
n=33\end{array}$ & $\begin{array}{c}0,801 \\
(1,348 ; 0,595) \\
n=126\end{array}$ & $\begin{array}{c}1,114^{*} \\
(1,469 ; 0,759) \\
n=31\end{array}$ & $\begin{array}{c}1,305^{*} \\
(1,787 ; 0,913) \\
\mathrm{p}=0,00426, \mathrm{n}=28\end{array}$ & $\begin{array}{c}0,709^{*} \\
(0,800 ; 0,590) \\
\mathrm{p}=0,01070, \mathrm{n}=32\end{array}$ & $\begin{array}{c}0,620^{*} \\
(0,905 ; 0,479) \\
p=0,00316, n=35\end{array}$ \\
\hline $\mathrm{L} / \mathrm{A}$ & 0,87 & 3,07 & 1,11 & 0,48 & 7,55 & 10,12 \\
\hline
\end{tabular}

Примітка: * - різниця між групою або підгрупою макросомів і групою нормосомів статистично достовірна при ймовірності помилки $p<0,05$. 
Таблиця 2

Медіанні значення Ме(Q3;Q1) вмісту кортизолу (нг/мл), інтерлейкіну-6 (пг/мл) та $\alpha$-амілази (од/л) у ротовій рідині та кількість обстежених осіб (n) в кожній групі чи підгрупі

\begin{tabular}{|c|c|c|c|c|c|c|}
\hline $\begin{array}{c}\text { Група, } \\
\text { підгрупа }\end{array}$ & Порівняння & Основна & Підгрупа 1 & Підгрупа 2 & Підгрупа 3 & Підгрупа 4 \\
\hline \multicolumn{7}{|c|}{ ВП I (4-6 років) } \\
\hline Кортизол & $\begin{array}{c}5,20 \\
(5,29 ; 4,4) \\
n=5\end{array}$ & $\begin{array}{c}5,15 \\
(6,24 ; 4,64) \\
n=20\end{array}$ & $\begin{array}{c}5,23 \\
(6,21 ; 4,71) \\
n=5\end{array}$ & $\begin{array}{c}4,54 \\
(4,67 ; 4,34) \\
n=5\end{array}$ & $\begin{array}{c}5,73 \\
(6,70 ; 5,50) \\
n=5\end{array}$ & $\begin{array}{c}5,65^{*} \\
(7,20 ; 5,34) \\
p=0,00902, n=5\end{array}$ \\
\hline ІЛ-6 & $\begin{array}{c}1,057 \\
(1,249 ; 0,603) \\
n=5\end{array}$ & $\begin{array}{c}1,384 \\
(4,594 ; 0,940) \\
n=20\end{array}$ & $\begin{array}{c}1,166 \\
(3,911 ; 0,888) \\
n=5\end{array}$ & $\begin{array}{c}0,957 \\
(1,266 ; 0,831) \\
n=5\end{array}$ & $\begin{array}{c}3,027 \\
(6,421 ; 1,387) \\
n=5\end{array}$ & $\begin{array}{c}3,985 \\
(12,22 ; 1,381) \\
n=5\end{array}$ \\
\hline$\alpha$-амілаза & $\begin{array}{c}271,78 \\
(282,87 ; 267,22) \\
n=7 \\
\end{array}$ & $\begin{array}{c}248,42^{*} \\
(253,30 ; 238,19) \\
\mathrm{p}=0,00112, \mathrm{n}=28\end{array}$ & $\begin{array}{c}246,45^{*} \\
(252,05 ; 242,16) \\
\mathrm{p}=0,00574, \mathrm{n}=11 \\
\end{array}$ & $\begin{array}{c}252,01 * \\
(258,93 ; 242,19) \\
\mathrm{p}=0,01013, \mathrm{n}=6\end{array}$ & $\begin{array}{c}264,12 \\
(269,30 ; 250,56) \\
n=5\end{array}$ & $\begin{array}{c}234,25^{*} \\
(244,98 ; 228,06) \\
\mathrm{p}=0,00270, \mathrm{n}=6 \\
\end{array}$ \\
\hline \multicolumn{7}{|c|}{ ВП II (7-11 років) } \\
\hline Кортизол & $\begin{array}{c}5,12 \\
(5,55 ; 4,65) \\
n=6\end{array}$ & $\begin{array}{c}6,10 \\
(6,93 ; 4,98) \\
n=20\end{array}$ & $\begin{array}{c}5,72 \\
(6,79 ; 4,44) \\
n=5\end{array}$ & $\begin{array}{c}4,90 \\
(5,00 ; 4,70) \\
n=5\end{array}$ & $\begin{array}{c}6,29 * \\
(7,34 ; 5,90) \\
p=0,04720, n=5\end{array}$ & $\begin{array}{c}6,90 * \\
(7,17 ; 6,70) \\
p=0,00902, n=5\end{array}$ \\
\hline ІЛ-6 & $\begin{array}{c}1,153 \\
(1,460 ; 0,885), n=5 \\
\end{array}$ & $\begin{array}{c}1,102 \\
(3,630 ; 0,746), n=20\end{array}$ & $\begin{array}{c}1,336 \\
(1,522 ; 0,477), n=5 \\
\end{array}$ & $\begin{array}{c}0,789 \\
(0,793 ; 0,766), \mathrm{n}=5 \\
\end{array}$ & $\begin{array}{c}3,262 \\
(6,187 ; 0,686), n=5 \\
\end{array}$ & $\begin{array}{c}4,733 \\
(11,500 ; 1,672), n=5\end{array}$ \\
\hline$\alpha$-амілаза & $\begin{array}{c}268,73 \\
(274,70 ; 265,55) \\
n=8\end{array}$ & $\begin{array}{c}261,22 \\
(269,99 ; 254,91) \\
n=26\end{array}$ & $\begin{array}{c}266,67 \\
(268,41 ; 255,73) \\
n=8\end{array}$ & $\begin{array}{c}271,72 \\
(272,96 ; 263,75) \\
n=6\end{array}$ & $\begin{array}{c}261,71 \\
(266,02 ; 253,05) \\
n=6\end{array}$ & $\begin{array}{c}255,21 * \\
(256,63 ; 252,46) \\
p=0,02819, n=6\end{array}$ \\
\hline \multicolumn{7}{|c|}{ ВП ІІІ (12-17 років) } \\
\hline Кортизол & $\begin{array}{c}6,61 \\
(7,10 ; 4,74), n=5\end{array}$ & $\begin{array}{c}6,83 \\
(7,33 ; 5,69), n=20\end{array}$ & $\begin{array}{c}6,76 \\
(6,9 ; 5,34), n=5\end{array}$ & $\begin{array}{c}5,30 \\
(5,80 ; 4,92), n=5\end{array}$ & $\begin{array}{c}7,32 \\
(8,12 ; 7,20), n=5\end{array}$ & $\begin{array}{c}7,34 \\
(9,16 ; 6,76), n=5\end{array}$ \\
\hline ІЛ-6 & $\begin{array}{c}0,972 \\
(1,639 ; 0,607), n=6\end{array}$ & $\begin{array}{c}1,520 \\
(3,657 ; 1,045), n=20\end{array}$ & $\begin{array}{c}1,131 \\
(1,636 ; 0,938), n=5\end{array}$ & $\begin{array}{c}1,14 \\
(1,584 ; 1,081), \mathrm{n}=5\end{array}$ & $\begin{array}{c}3,549 \\
(5,556 ; 1,333), n=5\end{array}$ & $\begin{array}{c}3,981 \\
(8,622 ; 1,456), n=5\end{array}$ \\
\hline$\alpha$-амілаза & $\begin{array}{c}264,05 \\
(271,02 ; 262,04) \\
n=8\end{array}$ & $\begin{array}{c}248,33 * \\
(261,49 ; 233,53) \\
\mathrm{p}=0,00818, \mathrm{n}=20\end{array}$ & $\begin{array}{c}259,02 \\
(264,30 ; 234,23) \\
n=5\end{array}$ & $\begin{array}{c}261,74 \\
(263,93 ; 261,39) \\
n=5\end{array}$ & $\begin{array}{c}241,21 * \\
(244,15 ; 234,00) \\
\mathrm{p}=0,00541, n=5\end{array}$ & $\begin{array}{c}233,48^{*} \\
(255,25 ; 223,65) \\
\mathrm{p}=0,00842, \mathrm{n}=5\end{array}$ \\
\hline \multicolumn{7}{|c|}{ ВП IV (18-34 роки) } \\
\hline Кортизол & $\begin{array}{c}6,19 \\
(6,39 ; 4,44) \\
n=7\end{array}$ & $\begin{array}{c}7,16^{*} \\
(7,97 ; 6,27) \\
\mathrm{p}=0,01497, \mathrm{n}=28\end{array}$ & $\begin{array}{c}6,95 \\
(7,06 ; 6,44) \\
n=7\end{array}$ & $\begin{array}{c}5,23 \\
(5,50 ; 4,45) \\
n=5\end{array}$ & $\begin{array}{c}7,21^{*} \\
(7,70 ; 6,72) \\
\mathrm{p}=0,01272, \mathrm{n}=7\end{array}$ & $\begin{array}{c}8,40^{*} \\
(9,11 ; 7,73) \\
\mathrm{p}=0,00086, \mathrm{n}=9\end{array}$ \\
\hline ІЛ-6 & $\begin{array}{c}0,890 \\
(1,088 ; 0,669) \\
n=6\end{array}$ & $\begin{array}{c}1,325 \\
(2,642 ; 0,747) \\
n=20\end{array}$ & $\begin{array}{c}0,708 \\
(0,968 ; 0,338) \\
n=5\end{array}$ & $\begin{array}{c}1,194 \\
(1,573 ; 0,466) \\
n=5\end{array}$ & $\begin{array}{c}1,859 * \\
(2,560 ; 1,456) \\
p=0,04461, n=5\end{array}$ & $\begin{array}{c}3,668^{*} \\
(5,688 ; 2,889) \\
\mathrm{p}=0,02846, \mathrm{n}=5\end{array}$ \\
\hline$\alpha$-амілаза & $\begin{array}{c}241,87 \\
(259,85 ; 239,03) \\
n=8 \\
\end{array}$ & $\begin{array}{c}245,29 \\
(256,71 ; 214,64) \\
n=36\end{array}$ & $\begin{array}{c}256,9 \\
(267,44 ; 254,13) \\
n=8\end{array}$ & $\begin{array}{c}259,68 \\
(270,14 ; 247,26) \\
n=7 \\
\end{array}$ & $\begin{array}{c}229,28 * \\
(235,00 ; 211,12) \\
\mathrm{p}=0,02689, \mathrm{n}=9\end{array}$ & $\begin{array}{c}211,04^{*} \\
(232,65 ; 193,33) \\
\mathrm{p}=0,03180, \mathrm{n}=12\end{array}$ \\
\hline \multicolumn{7}{|c|}{ ВП V (35-44 роки) } \\
\hline Кортизол & $\begin{array}{c}5,57 \\
(6,09 ; 5,10) \\
n=7\end{array}$ & $\begin{array}{c}8,13^{*} \\
(8,97 ; 6,82) \\
\mathrm{p}=0,00292, \mathrm{n}=23\end{array}$ & $\begin{array}{c}7,52 \\
(8,01 ; 6,14) \\
n=5\end{array}$ & $\begin{array}{c}6,83 \\
(7,05 ; 6,00) \\
n=5\end{array}$ & $\begin{array}{c}8,29 * \\
(8,99 ; 7,14) \\
\mathrm{p}=0,00664, \mathrm{n}=6\end{array}$ & $\begin{array}{c}9,47^{*} \\
(10,63 ; 8,82) \\
\mathrm{p}=0,00175, \mathrm{n}=7\end{array}$ \\
\hline ІЛ-6 & $\begin{array}{c}0,996 \\
(1,567 ; 0,243) \\
n=6\end{array}$ & $\begin{array}{c}1,406 \\
(4,078 ; 0,994) \\
n=20\end{array}$ & $\begin{array}{c}0,992 \\
(0,994 ; 0,876) \\
n=5\end{array}$ & $\begin{array}{c}1,190 \\
(1,206 ; 0,850) \\
n=5\end{array}$ & $\begin{array}{c}3,215^{*} \\
(5,881 ; 2,051) \\
\mathrm{p}=0,02828, \mathrm{n}=5\end{array}$ & $\begin{array}{c}4,273^{*} \\
(11,690 ; 4,013) \\
p=0,00902, n=5\end{array}$ \\
\hline$\alpha$-амілаза & $\begin{array}{c}240,01 \\
(265,46 ; 235,51) \\
n=10\end{array}$ & $\begin{array}{c}241,55 \\
(255,33 ; 201,82) \\
n=36\end{array}$ & $\begin{array}{c}256,87 \\
(272,22 ; 253,16) \\
n=8\end{array}$ & $\begin{array}{c}259,63 \\
(264,61 ; 258,13) \\
n=6\end{array}$ & $\begin{array}{c}223,17 \\
(236,52 ; 197,48) \\
n=7\end{array}$ & $\begin{array}{c}212,03 * \\
(230,91 ; 191,55) \\
\mathrm{p}=0,00274, \mathrm{n}=15\end{array}$ \\
\hline \multicolumn{7}{|c|}{ ВП VI (45-55 років) } \\
\hline Кортизол & $\begin{array}{c}7,00 \\
(7,11 ; 5,76) \\
n=5\end{array}$ & $\begin{array}{c}8,41 * \\
(12,28 ; 7,58) \\
\mathrm{p}=0,01482, \mathrm{n}=17\end{array}$ & $\begin{array}{c}8,03 \\
(8,44 ; 7,33) \\
n=4\end{array}$ & $\begin{array}{c}7,00 \\
(7,1 ; 6,2) \\
n=3\end{array}$ & $\begin{array}{c}10,77^{*} \\
(12,68 ; 9,11) \\
\mathrm{p}=0,01431, \mathrm{n}=4\end{array}$ & $\begin{array}{c}12,5^{*} \\
(14,20 ; 8,41) \\
p=0,00902, n=6\end{array}$ \\
\hline ІЛ-6 & $\begin{array}{c}1,166 \\
(1,526 ; 0,465), n=5\end{array}$ & $\begin{array}{c}1,650 \\
(4,324 ; 0,703), n=15\end{array}$ & $\begin{array}{c}0,983 \\
(1,418 ; 0,687), n=4\end{array}$ & $\begin{array}{c}1,390 \\
(1,667 ; 0,944), n=3\end{array}$ & $\begin{array}{c}4,480 \\
(11,130 ; 3,065), n=3\end{array}$ & $\begin{array}{c}4,167 \\
(9,638 ; 0,683), n=5\end{array}$ \\
\hline$\alpha$-амілаза & $\begin{array}{c}246,25 \\
(259,62 ; 241,32) \\
n=6\end{array}$ & $\begin{array}{c}221,12 \\
(259,37 ; 210,65) \\
n=17\end{array}$ & $\begin{array}{c}258,23 \\
(269,10 ; 246,49) \\
n=4\end{array}$ & $\begin{array}{c}265,48 \\
(277,00 ; 262,43) \\
n=3\end{array}$ & $\begin{array}{c}217,23^{*} \\
(224,07 ; 204,38) \\
\mathrm{p}=0,01902, \mathrm{n}=4\end{array}$ & $\begin{array}{c}209,51^{*} \\
(211,15 ; 202,78) \\
p=0,00395, n=6\end{array}$ \\
\hline \multicolumn{7}{|c|}{ Усі вікові періоди разом } \\
\hline Кортизол & $\begin{array}{c}5,43 \\
(6,42 ; 4,67) \\
n=35 \\
\end{array}$ & $\begin{array}{c}6,98^{*} \\
(8,22 ; 5,54) \\
\mathrm{p}=0,00003, \mathrm{n}=128\end{array}$ & $\begin{array}{c}6,68^{*} \\
(7,14 ; 5,31) \\
\mathrm{p}=0,01169, \mathrm{n}=31\end{array}$ & $\begin{array}{c}5,01 \\
(5,82 ; 4,52) \\
n=28 \\
\end{array}$ & $\begin{array}{c}7,27^{*} \\
(8,22 ; 6,63) \\
\mathrm{p}=0,00000, \mathrm{n}=32\end{array}$ & $\begin{array}{c}8,41^{*} \\
(9,22 ; 7,19) \\
\mathrm{p}=0,00000, \mathrm{n}=37\end{array}$ \\
\hline ІЛ-6 & $\begin{array}{c}1,037 \\
(1,470 ; 0,576) \\
n=32\end{array}$ & $\begin{array}{c}1,390^{*} \\
(3,983 ; 0,829) \\
\mathrm{p}=0,00214, \mathrm{n}=115\end{array}$ & $\begin{array}{c}0,992 \\
(1,522 ; 0,643) \\
\mathrm{n}=29\end{array}$ & $\begin{array}{c}1,019 \\
(1,297 ; 0,719) \\
n=28\end{array}$ & $\begin{array}{c}3,121 \\
(6,508 ; 1,374) \\
n=28\end{array}$ & $\begin{array}{c}4,090 \\
(10,540 ; 1,510) \\
n=30\end{array}$ \\
\hline$\alpha$-амілаза & $\begin{array}{c}262,30 \\
(270,25 ; 241,46) \\
n=47\end{array}$ & $\begin{array}{c}249,26^{*} \\
(260,99 ; 224,56) \\
\mathrm{p}=0,00041, n=163\end{array}$ & $\begin{array}{c}255,14 \\
(267,62 ; 249,12) \\
n=44\end{array}$ & $\begin{array}{c}261,37 \\
(270,57 ; 252,34) \\
n=33\end{array}$ & $\begin{array}{c}233,54^{*} \\
(247,27 ; 221,12) \\
\mathrm{p}=0,00000, \mathrm{n}=36\end{array}$ & $\begin{array}{c}219,77^{*} \\
(250,14 ; 200,44) \\
p=0,00000, n=50\end{array}$ \\
\hline
\end{tabular}

Примітка: * - різниця між групою або підгрупою макросомів і групою нормосомів статистично достовірна при ймовірності помилки $p<0,05$. 
Таблиця 3

Медіанні значення Ме(Q3;Q1) показників антиоксидантно-прооксидантного статусу у ротовій рідині учасників дослідження: супероксиддисмутаза (ум.од/ г білка), каталаза (мкмоль/хв на г білка), ТБК-АП (нмоль/мл) та кількість обстежених осіб (n) в кожній групі чи підгрупі

\begin{tabular}{|c|c|c|c|c|c|c|}
\hline $\begin{array}{c}\text { Група, } \\
\text { підгрупа }\end{array}$ & Порівняння & Основна & Підгрупа 1 & Підгрупа 2 & Підгрупа 3 & Підгрупа 4 \\
\hline \multicolumn{7}{|c|}{ ВП I (4-6 років) } \\
\hline СОД & $\begin{array}{c}0,20 \\
(0,21-0,18) \\
n=7\end{array}$ & $\begin{array}{c}0,17 * \\
(0,19 ; 0,15) \\
\mathrm{p}=0,03992, \mathrm{n}=22\end{array}$ & $\begin{array}{c}0,19 \\
(0,19 ; 0,18) \\
n=7\end{array}$ & $\begin{array}{c}0,19 \\
(0,20 ; 0,18) \\
n=5\end{array}$ & $\begin{array}{c}0,14^{*} \\
(0,14 ; 0,13) \\
\mathrm{p}=0,03985, \mathrm{n}=5\end{array}$ & $\begin{array}{c}0,16^{*} \\
(0,17 ; 0,15) \\
\mathrm{p}=0,00428, \mathrm{n}=5\end{array}$ \\
\hline Каталаза & $\begin{array}{c}0,83 \\
(0,85 ; 0,70) \\
n=7\end{array}$ & $\begin{array}{c}0,71^{*} \\
(0,76 ; 0,56) \\
\mathrm{p}=0,03311, \mathrm{n}=22\end{array}$ & $\begin{array}{c}0,73 \\
(0,79 ; 0,71) \\
n=7\end{array}$ & $\begin{array}{c}0,78 \\
(0,78 ; 0,72) \\
n=5\end{array}$ & $\begin{array}{c}0,50 * \\
(0,55 ; 0,48) \\
\mathrm{p}=0,04413, \mathrm{n}=5\end{array}$ & $\begin{array}{c}0,63^{*} \\
(0,64 ; 0,55) \\
\mathrm{p}=0,00617, \mathrm{n}=5\end{array}$ \\
\hline ТБК-АП & $\begin{array}{c}0,25 \\
(0,27 ; 0,16) \\
n=7 \\
\end{array}$ & $\begin{array}{c}0,46 \\
(0,50 ; 0,40) \\
\mathrm{p}=0,00009, \mathrm{n}=22\end{array}$ & $\begin{array}{c}0,40 \\
(0,46 ; 0,38) \\
\mathrm{p}=0,00173, \mathrm{n}=7\end{array}$ & $\begin{array}{c}0,47 \\
(0,50 ; 0,40) \\
\mathrm{p}=0,00436, \mathrm{n}=5\end{array}$ & $\begin{array}{c}0,53 \\
(0,54 ; 0,43) \\
\mathrm{p}=0,00441, \mathrm{n}=5\end{array}$ & $\begin{array}{c}0,47 \\
(0,49 ; 0,44) \\
\mathrm{p}=0,00441, \mathrm{n}=5\end{array}$ \\
\hline \multicolumn{7}{|c|}{ ВП ІІ (7-11 років) } \\
\hline СОД & $\begin{array}{c}0,27 \\
(0,28 ; 0,26) \\
n=7\end{array}$ & $\begin{array}{c}0,25 \\
(0,26 ; 0,24) \\
n=24\end{array}$ & $\begin{array}{c}0,27 \\
(0,29 ; 0,27) \\
n=6\end{array}$ & $\begin{array}{c}0,25 \\
(0,26 ; 0,25) \\
n=6\end{array}$ & $\begin{array}{c}0,26^{*} \\
(0,26 ; 0,24) \\
\mathrm{p}=0,03937, \mathrm{n}=6\end{array}$ & $\begin{array}{c}0,22 * \\
(0,24 ; 0,20) \\
\mathrm{p}=0,00509, \mathrm{n}=6\end{array}$ \\
\hline Каталаза & $\begin{array}{c}0,95 \\
(0,96 ; 0,84) \\
n=7\end{array}$ & $\begin{array}{c}0,74 \\
(0,85 ; 0,70) \\
n=24\end{array}$ & $\begin{array}{c}0,87 \\
(0,90 ; 0,77) \\
n=6 \\
\end{array}$ & $\begin{array}{c}0,85 \\
(0,86 ; 0,79) \\
\mathrm{n}=6 \\
\end{array}$ & $\begin{array}{c}0,73^{*} \\
(0,77 ; 0,72) \\
\mathrm{p}=0,03726, \mathrm{n}=6\end{array}$ & $\begin{array}{c}0,67 * \\
(0,67 ; 0,60) \\
\mathrm{p}=0,00259, \mathrm{n}=6\end{array}$ \\
\hline ТБК-АП & $\begin{array}{c}0,32(0,36 ; 0,20) \\
n=7\end{array}$ & $\begin{array}{c}0,51^{*} \\
(0,62 ; 0,39) \\
\mathrm{p}=0,00129, \mathrm{n}=24\end{array}$ & $\begin{array}{c}0,35 \\
(0,37 ; 0,27) \\
n=6\end{array}$ & $\begin{array}{c}0,51^{*} \\
(0,53 ; 0,43) \\
\mathrm{p}=0,00620, \mathrm{n}=6\end{array}$ & $\begin{array}{c}0,60 * \\
(0,66 ; 0,53) \\
\mathrm{p}=0,00259, \mathrm{n}=6\end{array}$ & $\begin{array}{c}0,62^{*} \\
(0,65 ; 0,47) \\
\mathrm{p}=0,00252, \mathrm{n}=6\end{array}$ \\
\hline \multicolumn{7}{|c|}{ ВП ІІІ (12-17 років) } \\
\hline СОД & $\begin{array}{c}0,28 \\
(0,30 ; 0,24), n=8\end{array}$ & $\begin{array}{c}0,25 \\
(0,27 ; 0,22), n=20\end{array}$ & $\begin{array}{c}0,28 \\
(0,28 ; 0,24), n=5\end{array}$ & $\begin{array}{c}0,26 \\
(0,28 ; 0,24), n=5\end{array}$ & $\begin{array}{c}0,25 \\
(0,25 ; 0,22), n=5\end{array}$ & $\begin{array}{c}0,22 \\
(0,23 ; 0,20), n=5\end{array}$ \\
\hline Каталаза & $\begin{array}{c}0,95 \\
(1,03 ; 0,77) \\
\mathrm{n}=8\end{array}$ & $\begin{array}{c}0,76^{*} \\
(0,86 ; 0,68) \\
\mathrm{p}=0,01164, \mathrm{n}=20\end{array}$ & $\begin{array}{c}0,87 \\
(0,89 ; 0,69) \\
\mathrm{n}=5\end{array}$ & $\begin{array}{c}0,77 \\
(0,89 ; 0,67) \\
n=5\end{array}$ & $\begin{array}{c}0,75^{*} \\
(0,76 ; 0,69) \\
\mathrm{p}=0,03355, \mathrm{n}=5\end{array}$ & $\begin{array}{c}0,70^{*} \\
0,76 ; 0,68) \\
\mathrm{p}=0,02271, \mathrm{n}=5\end{array}$ \\
\hline ТБК-АП & $\begin{array}{c}0,39 \\
(0,40 ; 0,31) \\
n=8 \\
\end{array}$ & $\begin{array}{c}0,57^{*} \\
(0,65-0,47) \\
\mathrm{p}=0,00054, \mathrm{n}=20\end{array}$ & $\begin{array}{c}0,47 \\
(0,50 ; 0,36) \\
\mathrm{n}=5 \\
\end{array}$ & $\begin{array}{c}0,56^{*} \\
(0,58 ; 0,44) \\
\mathrm{p}=0,00333, \mathrm{n}=5\end{array}$ & $\begin{array}{c}0,68 * \\
(0,80 ; 0,58) \\
\mathrm{p}=0,00333, \mathrm{n}=5\end{array}$ & $\begin{array}{c}0,64 * \\
(0,98 ; 0,61) \\
\mathrm{p}=0,00328, \mathrm{n}=5\end{array}$ \\
\hline \multicolumn{7}{|c|}{ ВП IV (18-34 роки) } \\
\hline СОД & $\begin{array}{c}0,48 \\
(0,50 ; 0,46) \\
n=8\end{array}$ & $\begin{array}{c}0,37 * \\
(0,41 ; 0,28) \\
\mathrm{p}=0,00001, \mathrm{n}=34\end{array}$ & $\begin{array}{c}0,40^{*} \\
(0,42 ; 0,29) \\
\mathrm{p}=0,00060, \mathrm{n}=8\end{array}$ & $\begin{array}{c}0,43 \\
(0,46 ; 0,41) \\
\mathrm{n}=6\end{array}$ & $\begin{array}{c}0,38^{*} \\
(0,40 ; 0,36) \\
\mathrm{p}=0,00019, \mathrm{n}=9\end{array}$ & $\begin{array}{c}0,22^{*} \\
(0,33 ; 0,20) \\
\mathrm{p}=0,00007, \mathrm{n}=11\end{array}$ \\
\hline Каталаза & $\begin{array}{c}1,03 \\
(1,09 ; 0,97) \\
n=8\end{array}$ & $\begin{array}{c}0,70^{*} \\
(0,8 ; 0,67) \\
\mathrm{p}=0,00004, \mathrm{n}=31\end{array}$ & $\begin{array}{c}0,74^{*} \\
(1,01 ; 0,71) \\
\mathrm{p}=0,00177, \mathrm{n}=7\end{array}$ & $\begin{array}{c}0,70 \\
(0,82 ; 0,69) \\
n=7\end{array}$ & $\begin{array}{c}0,72^{*} \\
(0,80 ; 0,70) \\
\mathrm{p}=0,00041, \mathrm{n}=7\end{array}$ & $\begin{array}{c}0,67^{*} \\
(0,69 ; 0,60) \\
\mathrm{p}=0,00025, \mathrm{n}=10\end{array}$ \\
\hline ТБК-АП & $\begin{array}{c}0,40 \\
(0,43 ; 0,30) \\
n=8 \\
\end{array}$ & $\begin{array}{c}0,56^{*} \\
(0,70-0,49) \\
\mathrm{p}=0,00010, \mathrm{n}=35\end{array}$ & $\begin{array}{c}0,44 \\
(0,49 ; 0,36) \\
n=8 \\
\end{array}$ & $\begin{array}{c}0,52^{*} \\
(0,56 ; 0,42) \\
\mathrm{p}=0,03579, \mathrm{n}=7\end{array}$ & $\begin{array}{c}0,64^{*} \\
(0,69 ; 0,56) \\
\mathrm{p}=0,00016, \mathrm{n}=9\end{array}$ & $\begin{array}{c}0,73^{*} \\
(0,82 ; 0,67) \\
\mathrm{p}=0,00007, \mathrm{n}=11\end{array}$ \\
\hline \multicolumn{7}{|c|}{ ВП V (35-44 роки) } \\
\hline СОД & $\begin{array}{c}0,51 \\
(0,52 ; 0,45) \\
n=10\end{array}$ & $\begin{array}{c}0,35^{*} \\
(0,42 ; 0,26) \\
\mathrm{p}=0,00004, \mathrm{n}=33\end{array}$ & $\begin{array}{c}0,38^{*} \\
(0,47 ; 0,36) \\
\mathrm{p}=0,04373, \mathrm{n}=7\end{array}$ & $\begin{array}{c}0,42 * \\
(0,44 ; 0,41) \\
\mathrm{p}=0,01001, \mathrm{n}=6\end{array}$ & $\begin{array}{c}0,33^{*} \\
(0,39 ; 0,28) \\
\mathrm{p}=0,00103, \mathrm{n}=7\end{array}$ & $\begin{array}{c}0,22 * \\
(0,36 ; 0,19) \\
\mathrm{p}=0,00005, \mathrm{n}=13\end{array}$ \\
\hline Каталаза & $\begin{array}{c}0,99 \\
(1,02 ; 0,91) \\
n=10\end{array}$ & $\begin{array}{c}0,68^{*} \\
(0,76 ; 0,59) \\
\mathrm{p}=0,00001, \mathrm{n}=34\end{array}$ & $\begin{array}{c}0,71^{*} \\
(0,86 ; 0,69) \\
\mathrm{p}=0,00766, \mathrm{n}=8\end{array}$ & $\begin{array}{c}0,75^{*} \\
(0,78 ; 0,73) \\
\mathrm{p}=0,00581, \mathrm{n}=6\end{array}$ & $\begin{array}{c}0,66^{*} \\
(0,72 ; 0,62) \\
\mathrm{p}=0,00064, \mathrm{n}=7\end{array}$ & $\begin{array}{c}0,51^{*} \\
(0,68 ; 0,49) \\
\mathrm{p}=0,00006, \mathrm{n}=13\end{array}$ \\
\hline ТБК-АП & $\begin{array}{c}0,63 \\
(0,65 ; 0,58) \\
n=10\end{array}$ & $\begin{array}{c}0,84 \\
(1,52 ; 0,74) \\
\mathrm{p}=0,00026, \mathrm{n}=36\end{array}$ & $\begin{array}{c}0,76 \\
(0,81 ; 0,62) \\
\mathrm{n}=8 \\
\end{array}$ & $\begin{array}{c}0,77 \\
(0,79 ; 0,61) \\
n=6\end{array}$ & $\begin{array}{c}1,44^{*} \\
(1,49 ; 0,93) \\
\mathrm{p}=0,00063, \mathrm{n}=7\end{array}$ & $\begin{array}{c}1,61^{*} \\
(1,71 ; 0,86) \\
\mathrm{p}=0,00010, \mathrm{n}=15\end{array}$ \\
\hline \multicolumn{7}{|c|}{ ВП VI (45-55 років) } \\
\hline СОД & $\begin{array}{c}0,40 \\
(0,41 ; 0,39) \\
n=6\end{array}$ & $\begin{array}{c}0,29 * \\
(0,36 ; 0,19) \\
\mathrm{p}=0,00553, \mathrm{n}=17\end{array}$ & $\begin{array}{c}0,33 \\
(0,38 ; 0,29) \\
n=4\end{array}$ & $\begin{array}{c}0,36 \\
(0,40 ; 0,29) \\
n=3\end{array}$ & $\begin{array}{c}0,29^{*} \\
(0,31 ; 0,27) \\
\mathrm{p}=0,00916, \mathrm{n}=4\end{array}$ & $\begin{array}{c}0,19^{*} \\
(0,30 ; 0,17) \\
\mathrm{p}=0,00358, \mathrm{n}=6\end{array}$ \\
\hline Каталаза & $\begin{array}{c}1,00 \\
(1,05 ; 0,93) \\
n=6\end{array}$ & $\begin{array}{c}0,60^{*} \\
(0,75 ; 0,49) \\
\mathrm{p}=0,00040,=117\end{array}$ & $\begin{array}{c}0,68^{*} \\
(0,79 ; 0,61) \\
\mathrm{p}=0,01392, \mathrm{n}=4\end{array}$ & $\begin{array}{c}0,68^{*} \\
(0,76 ; 0,64) \\
\mathrm{p}=0,02014, \mathrm{n}=3\end{array}$ & $\begin{array}{c}0,52^{*} \\
(0,57 ; 0,51) \\
\mathrm{p}=0,01028, \mathrm{n}=4\end{array}$ & $\begin{array}{c}0,44^{*} \\
(0,70 ; 0,40) \\
\mathrm{p}=0,00395, \mathrm{n}=6\end{array}$ \\
\hline ТБК-АП & $\begin{array}{c}0,85 \\
(0,97 ; 0,70) \\
n=6\end{array}$ & $\begin{array}{c}1,20 * \\
(1,80 ; 0,96) \\
\mathrm{p}=0,02735, \mathrm{n}=17\end{array}$ & $\begin{array}{c}1,03 \\
(1,13 ; 0,90) \\
n=4\end{array}$ & $\begin{array}{c}1,12 \\
(1,34 ; 1,05) \\
n=3\end{array}$ & $\begin{array}{c}1,78 \\
(1,83 ; 1,50) \\
n=4\end{array}$ & $\begin{array}{c}1,80 \\
(1,92 ; 1,15) \\
n=6\end{array}$ \\
\hline \multicolumn{7}{|c|}{ Усі вікові періоди разом } \\
\hline СОД & $\begin{array}{c}0,39 \\
(0,48 ; 0,26) \\
n=46 \\
\end{array}$ & $\begin{array}{c}0,26^{*} \\
(0,36 ; 0,20) \\
\mathrm{p}=0,00001, n=150\end{array}$ & $\begin{array}{c}0,29 * \\
(0,38 ; 0,24) \\
\mathrm{p}=0,02297, \mathrm{n}=37\end{array}$ & $\begin{array}{c}0,28 \\
(0,42 ; 0,24) \\
n=31 \\
\end{array}$ & $\begin{array}{c}0,26^{*} \\
(0,35 ; 0,22) \\
\mathrm{p}=0,00127, \mathrm{n}=36\end{array}$ & $\begin{array}{c}0,21^{*} \\
(0,26 ; 0,18) \\
\mathrm{p}=0,00000, \mathrm{n}=46\end{array}$ \\
\hline Каталаза & $\begin{array}{c}0,97 \\
(1,03 ; 0,85) \\
n=46\end{array}$ & $\begin{array}{c}0,70 * \\
(0,78 ; 0,64) \\
\mathrm{p}=0,00000, \mathrm{n}=148\end{array}$ & $\begin{array}{c}0,74^{*} \\
(0,88 ; 0,70) \\
\mathrm{p}=0,00000, \mathrm{n}=37\end{array}$ & $\begin{array}{c}0,77^{*} \\
(0,86 ; 0,71) \\
\mathrm{p}=0,00001, \mathrm{n}=32\end{array}$ & $\begin{array}{c}0,70^{*} \\
(0,75 ; 0,59) \\
\mathrm{p}=0,00000, \mathrm{n}=34\end{array}$ & $\begin{array}{c}0,64^{*} \\
(0,70 ; 0,51) \\
\mathrm{p}=0,00000, \mathrm{n}=45\end{array}$ \\
\hline ТБК-АП & $\begin{array}{c}0,40 \\
(0,60 ; 0,28) \\
n=46\end{array}$ & $\begin{array}{c}0,61^{*} \\
(0,82 ; 0,47) \\
\mathrm{p}=0,00000, \mathrm{n}=154\end{array}$ & $\begin{array}{c}0,46 \\
(0,62 ; 0,36) \\
\mathrm{n}=38\end{array}$ & $\begin{array}{c}0,55^{*} \\
(0,59 ; 0,44) \\
\mathrm{p}=0,00207, \mathrm{n}=32\end{array}$ & $\begin{array}{c}0,66^{*} \\
(0,82 ; 0,53) \\
\mathrm{p}=0,00000, \mathrm{n}=36\end{array}$ & $\begin{array}{c}0,76^{*} \\
(1,35 ; 0,62) \\
\mathrm{p}=0,00000, \mathrm{n}=48\end{array}$ \\
\hline
\end{tabular}

Приітка: * - різниця між групою або підгрупою макросомів і групою нормосомів статистично достовірна при ймовірності помилки $p<0,05$. 


\section{Висновки:}

1. Нами було виявлено вірогідне підвищення вмісту лептину у ротовій рідині пацієнтів всіх вікових періодів підгруп 3 та 4, найбільш виражене у підгрупі 4, що очевидно було пов'язано із внутрішньоутробною гіперкортизолемією (та збільшенням маси жирової тканини). Із віком рівень лептину зростав. Водночас у осіб підгрупи 2 значення вмісту лептину були найменшими серед всіх учасників дослідження, що було, ймовірно, пов'язано із високим рівнем СТГ та відносною недостатністю жирової тканини. У підгрупі 1 рівень лептину практично в усіх вікових періодах вірогідно не відрізнявся від такого у групі порівняння. Рівень адипонектину був найменшим у підгрупах 3 та 4 (і знижувався із віком), залишався відносно високим у осіб підгрупи 2 та вірогідно не відрізнявся від групи порівняння в осіб підгрупи 1. Співвідношення лептин/адипонектин свідчило про формування метаболічного запалення та високий кардіометаболічний ризик у осіб підгруп 3 та 4, що сприяло збільшенню деструкції кісткової тканини та узгоджувалось із даними щодо схильності до високої інтенсивності карієсу у цих осіб.

2. У осіб підгруп 3 та 4 спостерігався вірогідно високий відносно групи порівняння рівень кортизолу, який зростав із віком (максимальні показники - у 4 групі), що підтверджувало наше припущення про загальний прозапальний стан та було пов'язано із первинною гіперкортизолемією. У осіб підгруп 1 та 2, навпаки, рівень кортизолу майже не збільшувався із віком, імовірно, внаслідок відносно високого рівня СТГ, який стимулює синтез альдостерону, опосередковано зменшуючи синтез кортизолу.

3. Виявлено зміни продукції ІЛ-6, рівень якого, порівняно 3 контролем, зростав у осіб підгруп 3 та 4. Ці зміни поглиблювались із віком, що детермінує схильність до розвитку метаболічного запалення.

4. У осіб підгруп 3 та 4 зафіксовано зниження активності $\alpha$-амілази ротової рідини, що відбувається внаслідок зміни кислотно-основних властивостей слини під впливом ацидогенних властивостей патогенних мікроорганізмів і продуктів їхньої життєдіяльності, та $\epsilon$ характерним для карієсу.

5. У осіб підгруп $2-4$ була виявлена інтенсифікація процесів ПОЛ, яка проявлялась зростанням рівня ТБК-АП та зниженням антиоксидантних ферментів СОД і каталази. У підгрупах 3 та 4 ці зміни були зафіксовані в усіх вікових періодах (очевидно, внаслідок прогресування метаболічного запалення), а в осіб групи 2 - тільки у молодому віці, що, ймовірно, було наслідком активуючого впливу СТГ на процеси ПОЛ.

Отже, прогноз стану твердих тканин зубів для осіб підгруп 1 та 2 є більш сприятливим, ніж для осіб підгруп 3 та 4. Проведені дослідження можуть бути використані для оцінювання патологічних змін у ротовій порожнині та встановлення біохімічних критеріїв ранньої та диференційної діагностики в осіб, які народились макросомами.

\section{References:}

1. Garmash OV. Osoblyvosti stomatolohichnoho statusu ditei, yaki narodylysia $\mathrm{z}$ makrosomiieiu, $\mathrm{u}$ period tymchasovoho prykusu. Visnyk problem biolohii i medytsyny.2018; 146(4):246-53. DOI: 10.29254/ 2077-4214-2018-4-1-146-246-253. [In Ukrainian].

2. Garmash OV. Dependence of caries intensity in individuals of the kharkiv region and the adjacent areas population, born with macrosomia, on the body mass index at birth. Svit medytsyny ta biolohii. 2019; 69(3):43-8. DOI: 10.26724/2079-8334-2019-3-69-4348.

3. Garmash OV. Oral health abnormalities in children born with macrosomia established during mixed dentition period. Wiad Lek. 2019; 72 (5 cz 1):823-831.

4. Palchevska S, Krstevska M, Shukarova E, Aluloska N, Jakimoska M, Kocevski D, et al. Comparing Preterm and Term Newborns Serum Adiponectin and Leptin Concentrations and their Correlations with Anthropometric Parameters. Maced J Med Sci. 2012, Oct $15 ; 5(3): 317-323$.

5. Pirsean C, Negut C, Stefan-van Staden RI, Dinu-Pirvu $\mathrm{CE}$, Armean P, Udeanu DI. The salivary levels of leptin and interleukin- 6 as potential inflammatory markers in children obesity. PLoS One. 2019; 14(1):e0210288. Published 2019, Jan 3. DOI: 10.1371/journal.pone.0210288.

6. Chen SM, Peng YJ, Wang CC, Su SL, Salter DM, Lee HS. Dexamethasone Down-regulates Osteocalcin in Bone Cells through Leptin Pathway. Int J Med Sci. 2018; 15(5):507-516. Doi:10.7150/ijms.21881.

7. Jayachandran T, Srinivasan B, Padmanabhan S. Salivary leptin levels in normal weight and overweight individuals and their correlation with orthodontic tooth movement. Angle Orthod. 2017, Sep; 87(5):739-744. DOI: 10.2319/120216-869.1.

8. Trubka IO. Biokhimichni pokaznyky rotovoi ridyny v ditei shkilnoho viku pry poiednanomu perebihu kariiesu y khronichnoho heneralizovanoho kataralnoho hinhivitu pid vplyvom likuvalnoprofilaktychnoho kompleksu. Zdorove rebenka.2018; 13(3):269-73. [In Ukrainian].

9. Kryshtop VV, Kurchanynova MH. Byokhymychesky e pokazately okyslytelnoho stressa $\mathrm{V}$ rotovoi zhydkosty u studentov s raznym stomatolohycheskym statusom y kachestvom zhyzny. Mezhdunarodnyi zhurnal prykladnykh y fundamentalnykh yssledovanyi. 2014; 10(2):81-5. [In Russian].

10. Markovska IV, Sokolova II, Markovska OV. Vmist zahalnoho bilka ta aktyvnist deiakykh fermentiv u rotovii ridyni shchuriv za umov vplyvu elektromahnitnoho vyprominiuvannia. Visnyk problem biolohii $\mathrm{i}$ medytsyny. 2019; 148(1):340-3. [In Ukrainian].

11. Woolliams JA, Wiener G, Anderson PH, McMurray $\mathrm{CH}$. Variation in the activities of glutathione peroxidase and superoxide dismutase and in the concentration of copper in the blood in various breed crosses of sheep. Res Vet Sci. 1983 May; 34(3):253-6.

12. Koroliuk MA, Yvanova LY, Maiorova YH, Tokarev VE. Metod opredelenyia aktyvnosty katalazy. Lab. delo.1988; 1:16-8. [In Russian].

13. Menshchykova EB, Lankyn VZ, Zenkov NK, Bondar YA, Kruhovykh NF, Trufakyn VA. Okyslytelnyi stress. Prooksydanty y antyoksydanty. Moskva: Fyrma «Slovo»; 2006. P.556. [In Russian]. 
14. López-Jaramillo P, Gómez-Arbeláez D, López-López $\mathrm{J}$, López-López C, Martínez-Ortega J, GómezRodríguez A, et al. The role of leptin/adiponectin ratio in metabolic syndrome and diabetes. Horm Mol Biol Clin Investig. 2014, Apr; 18(1):37-45. Doi: 10.1515/hmbci-2013-0053.

15. Tiazhka OV, Zahorodnia YaM. Stan perekysnoho okyslennia lipidiv ta antyoksydantnoi systemy u ditei riznoho viku. Perynatolohyia y pedyatryia. 2016; 66(2):101-5. DOI: 10.15574/PP.2016.66.101. [In Ukrainian].

16. Guo W, Li F, Zhu C, Wang B, Wang K, Dai C, et al. Effect of hypercortisolism on bone mineral density and bone metabolism: A potential protective effect of adrenocorticotropic hormone in patients with Cushing's disease. J Int Med Res. 2018, Jan; 46(1):492-503. Doi: 10.1177/0300060517725660.

17. Spät A, Hunyady L, Szanda G. Signaling Interactions in the Adrenal Cortex. Front. Endocrinol. 29 February 2016; 7:17. Doi: 10.3389/fendo.2016.00017.

18. Lahoda LS. Obgruntuvannia profilaktyky kariiesu zubiv $\mathrm{u}$ ditei, yaki prozhyvaiut $\mathrm{v}$ ekolohichno nespryiatlyvykh umovakh [dysertatsiia]. Lviv: Lvivsk. nats. med. un-t; 2019. P.200. [In Ukrainian].

19. Petrushanko AM, Hermanchuk SM. Zminy vlastyvostei rotovoi ridyny pid diieiu rozroblenykh metodiv likuvannia zapalennia tkanyn parodonta $\mathrm{v}$ patsiientiv iz neznimnymy konstruktsiiamy zubnykh proteziv $\mathrm{u}$ porozhnyni rota $\mathrm{v}$ dynamitsi. Ukrainskyi stomatolohichnyi almanakh. 2015; (4):54-60. [In Ukrainian].

\section{УДК 616.316-008.8-078-06:616.314-002:618.33-007.1 ДИНАМИКА БИОХИМИЧЕСКИХ ПОКАЗАТЕ- ЛЕЙ РОТОВОЙ ЖИДКОСТИ КАК МАРКЕР РИ- СКА РАЗВИТИЯ КАРИОЗНЫХ ПОРАЖЕНИЙ У ЛИЦ РАЗНОГО ВОЗРАСТА, РОДИВШИХСЯ МАКРОСОМАМИ}

\section{O.В. Гармаш}

Харьковский нацииональной медицинский университет, кафедра терапевтической стоматологии, г. Харьков, Украина, ORCID ID: 0000-0001-7935-9371,

e-mail: o.v.garmash@gmail.com

Резюме. Высокая интенсивность кариеса у лиц, которые были рождены большими, к гестационному возрасту побуждает к поиску биохимических критериев ранней и дифференциальной диагностики.

Цель исследования - изучение взаимозависимости между динамикой уровней лептина, адипонектина, кортизола, ТБК-АП и ИЛ-6, а также активностью $\alpha$-амилазы, СОД и каталазы, в нестимулированной ротовой жидкости лиц популяции Харьковской области и прилегающих областей, которые родились с макросомией (учитывая их антропометрические показатели при рождении)/нормосомией и интенсивностью кариеса временных и постоянных зубов.
Материалы и методы исследования. Было обследовано 210 человек в возрасте от 4 до 55 лет. Участники исследования основной группы (макросомы-при-рождении) были разделены на подгруппы в зависимости от возраста и особенностей внутриутробного развития.

Результаты. У участников исследования, отнесённых к подгруппам 3 (большая длинна и большая масса тела при рождении) и 4 (средняя длинна тела, избыточная масса тела), выявлен значительный рост концентрации лептина и кортизола с одновременным снижением уровней адипонектина в ротовой жидкости, что свидетельствует о дисбалансе адипокинов и формировании метаболического воспаления. Рост уровня ТБК-АП и снижение активности супероксиддисмутазы, каталазы и $\alpha$-амилазы, а также повышение уровня интерлейкина-6 в ротовой жидкости негативно влияют на состояние костной ткани и согласуются с данными о склонности к высокой интенсивности кариеса у этих лиц. В подгруппах 1 (гармонично развитые при рождении) и 2 (большая длинна и относительно пониженная масса тела при рождении), в условиях нашего исследования, более благоприятный прогноз состояния костной ткани и твердых тканей зубов, в частности.

Выводы. Прогноз состояния твердых тканей зуба у лиц подгруппы 1 и 2 более благоприятен, чем у лиц подгруппы 3 и 4.

Ключевые слова: макросомия плода, отдаленные последствия, кариес, ротовая жидкость, биохимические маркеры.

UDC 616.316-008.8-078-06:616.314-002:618.33-007.1

DYNAMICS OF BIOCHEMICAL INDICES OF THE ORAL FLUID AS A MARKER OF THE RISK OF THE DEVELOPMENT OF CARIES IN PERSONS OF DIFFERENT AGES BORN MACROSOMIC

\section{O.V. Garmash}

Kharkiv national medical university, Therapeutic dentistry department, Kharkiv, Ukraine, ORCID ID: 0000-0001-7935-9371, e-mail: o.v.garmash@gmail.com

Abstract. The high intensity of caries in individuals who were born macrosomic prompts to search for biochemical criteria for early and differential diagnosis.

The purpose of the study is to reveal the relationship between the dynamics of levels of leptin, adiponectin, cortisol, TBK-AP, and IL-6 as well as the activity of $\alpha$-amylase, superoxide dismutase and catalase, in an unstimulated oral fluid in persons born macrosomic (given their anthropometric parameters at birth) / normosomic and intensity of caries of the deciduous and permanent teeth in the Kharkiv and adjacent provinces.

Materials and Methods. The macrosomic-atbirth study participants were divided into subgroups based on age and pre-natal developmental characteristics. 
Subgroup 1 included persons long, harmoniously developed at birth, since their height-weight indices at the time of birth were comparable to those of the comparison group. According to the hormonal developmental features, these individuals had a prenatally balanced cortisolto-somatotropic hormone ratio.

Subgroup 2 included persons with increased body length and relatively low birth weight at birth, that is, their prenatal development occurred against an elevated somatotropic hormone levels and relative cortisol deficiency background.

Subgroup 3 included persons who had large length and large body weight at birth. That is, individuals who had elevated levels of somatotropic hormone and cortisol.

Subgroup 4 included participants in the study who had an average body length at birth, but a pronounced excess body weight, their development took place at elevated levels of cortisol and with a lack of somatotropic hormone.

Results. A significant increase in the level of leptin in the oral fluid of participants in Subgroups 3 and 4, with most pronounced in Subgroup 4, has been revealed. The level of leptin increased with age. The leptin level in persons of Subgroup 2 was the lowest among all participants in the study. In Subgroup 1, the level of leptin in participants of virtually all ages was not significantly different from that in the Comparison group. A decrease in the level of adiponectin was observed to occur in Subgroups 3 and 4, and it decreased with age, the level remained relatively high in_Subgroup 2, and it did not differ significantly in Subgroup 1 from the level in the Comparison group. The leptin-to-adiponectin ratio showed the formation of metabolic inflammation in Subgroups 3 and 4, which contributed to an increase in bone tissue destruction and were consistent with the data on the tendency to high intensity of caries in these persons. The persons in Subgroups 3 and 4 had a level of cortisol significantly higher than the Comparison group, and this level grew with age. In Subgroups 1 and 2, cortisol levels did not increase with age. Significant changes in the production of interleukin- 6 were detected. The level of interleukin-6 grew in Subgroups 3 and 4 as compared to the production in the control group. These changes deepened with age, which determines the tendency to develop metabolic inflammation. A decrease in oral $\alpha$-amylase activity was observed to occur in the Subgroups 3 and 4, which is characteristic of caries. Intensification of lipid peroxidation processes was found to occur in Subgroups 2-4. In Subgroups 3 and 4, these changes were recorded at all ages, and those in Subgroup 2 only at young age.

Conclusions. The prognosis for the condition of hard tooth tissues in persons of Subgroup 1 and 2 is more favorable than in persons of Subgroups 3 and 4 .

Keywords: fetal macrosomia, long-term consequences, caries, oral fluid, biochemical markers.

Стаття надійшла в редакцію 25.02. 2020 р. 